\title{
Dynamika modeli biznesu przedsiębiorstw w gospodarce cyfrowej - perspektywa monetyzacji
}

Prof. nadzw. dr hab. Marek Jabłoński
Wyższa Szkoła Bankowa w Poznaniu
Wydział Zamiejscowy w Chorzowie

Prof. nadzw. dr hab. Adam Jabłoński

Wyższa Szkoła Bankowa w Poznaniu Wydział Zamiejscowy w Chorzowie

Prof. nadzw dr hab. Agnieszka Anna Szpitter

Uniwersytet Gdański, Wydział Zarządzania

\section{Wprowadzenie}

Modele biznesu, jako koncepcja naukowa, obejmują szeroki zakres oddziaływania na współczesne definiowanie teorii w obszarze nauki o zarządzaniu i jakości. Są one rozpatrywane w ujęciu dynamicznym, szczególnie w kontekście dynamicznych zdolności ${ }^{1}$. W szerokim stopniu stanowią architekturę produktu lub usługi oraz przepływy informacji, w tym opis różnych podmiotów biznesowych i ich roli. Wskazują potencjalne korzyści dla różnych podmiotów biznesowych wraz z opisem źródeł przychodów ${ }^{2}$. Model biznesu powinien odpowiadać co najmniej na następujące pytania: „Jakie propozycje wartości są oferowane?”, „Kim są klienci?”, „Jak działają operacje?”, „Dlaczego model biznesu jest interesujący finansowo?". Cyfrowe modele biznesu powinny być skonstruowane z reprezentacji funkcjonalnej, opartej na pięciu kluczowych elementach: ludziach (użytkownikach), biznesie (zakresie usług z zastosowaniem „cyfrowo połączonych firm/grup firm”

1 D.J. Teece, Business models and dynamic capabilities, „Long Range Planning” 2018, vol. 51, no. 1.

2 P. Timmers, Business Models for Electronic Markets, „Electronic Markets” 1998, vol. 8, no. 2, s. 4. 
tworzących ekosystem biznesu), rzeczach (cyfrowo połączonych rzeczach - samochodach, rowerach, odtwarzaczach muzycznych itp.), danych, chmury obliczeniowej$^{3}$. Cyfrowe modele biznesu rewolucjonizują podejście do procesów zarządczych. Innowacyjne technologie sprawiają, że dotychczasowe formuły prowadzenia biznesu na podstawie tradycyjnych założeń łańcucha wartości nie mają zastosowania. Rewolucja cyfrowa dynamizuje modele biznesu. Rozwijają się tzw. rynki dwustronne. Dwustronny rynek, zwany także siecią dwustronną, jest platformą ekonomiczną mającą dwie odrębne grupy użytkowników, które zapewniają sobie wzajemne korzyści. Korzyści dla każdej grupy wykazują korzyści skali wynikające z popytu. Dwustronne platformy rynkowe wybierają odpowiednią cenę do obciążenia każdej grupy, gdzie jedna grupa "napędza” drugą ${ }^{4}$. Kluczową rolę odgrywają w tym aspekcie media społecznościowe. Jest wiele powodów, dla których ludzie korzystają z mediów społecznościowych. W sieci widzimy wiele mechanizmów, za pośrednictwem których ich właściciele próbują zarabiać na funkcjonalnościach owych mediów ${ }^{5}$.Zrozumienie potencjału gospodarki cyfrowej stwarza szanse na wytworzenie wartości ekonomicznych i społecznych. Tego typu formuły działania na globalnym rynku znacznie różnią się od „starego" podejścia do projektowania modeli biznesu. Obecnie należy wytworzyć atrakcyjną wartość dla interesariuszy - najczęściej o charakterze społecznym, a w konsekwencji dla korzyści ekonomicznych. Symbiotyczne podejście w tym zakresie jest możliwe ${ }^{6}$. Należy jednak jednoznacznie wskazać, że zarabianie jest oczywistym wymogiem każdego modelu biznesu. Konfiguracja skutecznych modeli biznesu powinna obejmować zestaw współzależnych działań, które można pogrupować wokół zadań związanych z identyfikacją klienta, jego zaangażowaniem, powiązaniami łańcucha wartości i przedmiotową monetyzacją7. Monetyzacja jest niezbędna do realizacji celów rozwojowych cyfrowych modeli biznesu i powinna być zabudowana w logice funkcjonowania projektowanego modelu biznesu. Dynamizacja modeli biznesu powinna być oparta na co najmniej dwóch filarach eksploatacji modeli biznesu:

3 M. Blaschke i wsp., Designing Business Models for the Digital Economy, [w:] G. Oswald, M. Kleinemeier (red.), Shaping the Digital Enterprise, Springer International Publishing, Switzerland 2017, s. 123-126.

4 A.S. Bataineh, R. Mizouni, M.E. Barachi, J. Bentahar, Monetizing Personal Data: A Two-Sided Market Approach, „Procedia Computer Science” 2016, no. 83, s. 472.

5 E.K. Clemons, The complex problem of monetizing virtual electronic social networks, „Decision Support Systems" 2009, no. 48, s. 51.

6 A. Jabłoński, M. Jabłoński, Social Business Models in the Digital Economy, New Concepts and Contemporary Challenges, Palgrave Macmillan, Springer Nature, Switzerland 2020.

7 C. Baden-Fuller, V. Mangematin, Business Models: A challenging agenda, „Strategic Organization" 2013, vol. 11, no. 4 , s. 418-427. 
- dynamice interakcji w trybie relacyjnym pomiędzy aktorami sieci wartości zabudowanej w modelu biznesu;

- dynamice stymulowanej przez schemat przyjętej monetyzacji kreowanej wartości.

Te dwa obszary dynamiki modeli biznesu, przenikając się, powinny tworzyć spójną strukturę modelu biznesu, rozumianą przez rynek. W innym przypadku trwałość modelu biznesu będzie zachwiana, a model biznesu będzie charakteryzować się ponadprzeciętnym poziomem labilności ${ }^{8}$. Czynnikiem stymulującym dynamikę modeli biznesu jest monetyzacja. Schematy monetyzacji silnie oddziałują na atrakcyjność cyfrowych modeli biznesu. Rodzaje monetyzacji stanowią element wspierający proces rozwoju modelu biznesu i warunek jego przetrwania. Od skuteczności monetyzacji zależy trwałość i stabilność projektowanego modelu biznesu. Tytułowa dynamika modeli biznesu, jak sądzimy, zależy od spójności wartości kreowanej przez model biznesu ze schematami monetyzacji. Oba te zagadnienia muszą być względem siebie symbiotyczne. Opracowanie ma charakter teoretyczny, a jego celem jest przedstawienie wyników badań bibliograficznych i prac konceptualnych służących identyfikacji i charakterystyce kluczowych determinant odpowiedzialnych za dynamikę modeli biznesu funkcjonujących w środowisku cyfrowym. Zakres rozdziału obejmuje zasady projektowania i implementacji modeli biznesu osadzonych w ekosystemie cyfrowym, w kontekście różnych schematów monetyzacji.

\section{Dynamika zmian w cyfrowych modelach biznesu a kontekst współczesnych koncepcji nowej gospodarki}

Dynamika w systemach działania ma fundamentalne znaczenie w kontekście współczesnych uwarunkowań rynkowych. Gospodarka cyfrowa przyspiesza procesy starzenia się produktów i skraca cykl ich życia. Ponieważ produkty i usługi są obecnie współzależne od cyklu życia modelu biznesu, dynamika, jako pojęcie, powinna być rozpatrywana łącznie z koncepcją modeli biznesu. Zmienność czynników egzogenicznych i endogenicznych sprawia, że należy uzależniać trwałość produktów i usług od trwałości modelu biznesu, w ramach którego są one dostarczane odbiorcom. Do poszukiwania sposobów zapewnienia trwałości modeli biznesu, a także dokonywania w nich zmian wydłużających ich cykl życia

8 M. Jabłoński, Labilność modeli biznesu a zarzq̨dzanie interfejsami w koncepcji ekonomii wspótdzielenia, „Przegląd Organizacji” 2017, nr 9, s. 13-21. 
w kontekście zmienności otoczenia zewnętrznego i wewnętrznego można zastosować założenia metody dynamiki systemowej. Cyfrowe modele biznesu rozwijają swoją dynamikę w ekosystemach działania (aby następnie regularnie się zakłócać), odnawiają się na stale zmieniających się rynkach ${ }^{9}$. Według Forrestera dynamika systemu budowana jest dwukierunkowo $\mathrm{w}$ aspektach komunikacyjnych między modelami mentalnymi i modelami symulacyjnymi. Modele mentalne są podstawą codziennych decyzji i zawierają ogromne ilości przechowywanych informacji. Jednak umysł człowieka nie do końca zrozumie, co dostępne informacje oznaczają w kategoriach zachowania. Symulacja komputerowa zapewnia połączenie danych z modelami myślowymi, a następnie dynamiczną wizualizację konsekwencji ${ }^{10}$. Metoda dynamiki systemowej (System Dynamics) umożliwia budowę modeli symulacji ciągłej. Pozwala ona modelować strukturę i dynamikę złożonych systemów i zachodzących w nich procesów. Uwzględnia przy tym występujące w tych systemach liczne sprzężenia zwrotne, które opisują zależności przyczynowo-skutkowe pomiędzy elementami badanego systemu. Fundamentalnym założeniem metody jest rozpatrywanie badanego systemu jako spójnej całości w kontekście jego dynamiki ${ }^{11}$. Dynamika systemów opiera się na twierdzeniu, że za zmiany i powstawanie problemów w systemie odpowiedzialna jest jego struktura determinująca zachowanie. Przyczyną powstania problemu jest cały system, wszystkie jego obszary. Nie należy zatem upatrywać źródła problemu tylko w jednym lub kilku jego elementach. Metoda dynamiki systemów odchodzi od linearnego stosunku: przyczyna - problem - skutek. Myśląc systemowo, należy analizować system całościowo, ponieważ to właśnie jego struktura generuje zachowanie się systemu prowadzące do powstania problemu ${ }^{12}$. Adekwatny dla wskazanego powyżej teoretycznego aspektu definiowania systemów jest model biznesu i jego dynamika. Konceptualizacja modeli biznesu zyskała wiele uwagi w literaturze przedmiotu, a obecna koncentracja badań przesuwa się z perspektywy statycznej na bardziej dynamiczną. Schaffer, Pfaff i Krcmar definiują dynamiczny model biznesu (Dynamic Business Model) jako złożony system powiązanych ze sobą składników mechanizmów tworzenia, dostarczania i wychwytywania wartości, który oddziałuje z heterogenicznymi wpływami wewnętrznymi i zewnętrznymi, prowadząc do ewolucji jego komponentów

$9 \quad$ M. Blaschke i wsp., Designing Business Models..., s. 127.

10 J.W. Forrester, Some Basic Concepts in System Dynamics, Sloan School of Management Massachusetts Institute of Technology, Cambridge 2009, s. 9.

11 R. Hoffmann, T. Protasowicki, Metoda dynamiki systemowej w modelowaniu złożonych systemów i procesów, „Biuletyn Instytutu Systemów Informatycznych” 2013, nr 12, s. 19.

12 P. Żukowski, Podstawy budowy modelu dynamiki systemu zarzqdzania oraz jego symulacja w organizacji gospodarczej (na podstawie metodologii dynamiki systemów J.W. Forrestera), „Przedsiębiorczość - Edukacja, Rola Przedsiębiorczości w Edukacji” 2012, nr 8, s. 334. 
i samego systemu ${ }^{13}$. Przedmiotowa koncepcja ma szczególne znaczenie dla projektowania i użytkowania cyfrowych modeli biznesu. Dynamika złożonych systemów, jakimi są cyfrowe modele biznesu, jest cechą wyróżniającą, co wynika z istoty tego typu bytów ontologicznych. Wchodzące w synergię z ekosystemami biznesu modele działania poprzez efekty skalowalności determinują zachowania po stronie popytowej. W ten sposób są w stanie zwiększać poziom swojego oddziaływania w czasoprzestrzeni społecznej i ekonomicznej. Dynamika zmian w cyfrowych modelach biznesu jest determinowana koncepcjami nowej gospodarki. Szczególne znaczenie w zakresie dynamizowania działania nowych bytów biznesowych mają algorytmy poznawcze (Cognitive Computing), które opisują platformy technologiczne, opierające się na dyscyplinach naukowych sztucznej inteligencji i przetwarzaniu sygnałów. Platformy te obejmują między innymi uczenie maszynowe, rozumowanie, przetwarzanie języka naturalnego, rozpoznawanie mowy i widzenie (rozpoznawanie obiektów), interakcje człowiek - komputer, generowanie dialogu i narracji ${ }^{14}$. „Dynamiczność” w kontekście tej formuły tworzenia wartości kształtuje i operacjonalizuje złożone obiekty, jakimi są cyfrowe modele biznesu. Zmiany rynkowe wymuszają potrzeby dostrajania modeli biznesu do oczekiwań rynku zarówno poprzez ich transformację cyfrową, jak i spełnianie założeń innowacyjnych koncepcji nowej gospodarki. Koncepcja algorytmów poznawczych wpisuje się w perspektywy rozwoju modeli biznesu w aspekcie nowej gospodarki cyfrowej15. W ramach poszukiwania nowych formuł dostarczania wartości powstają złożone twory techniczne charakteryzujące się oczekiwanymi funkcjonalnościami, zdolne do wchodzenia w dynamiczne interakcje z użytkownikami.

13 N. Schaffer, M. Pfaff, H. Krcmar, Dynamic business models: a comprehensive classification of literature, MCIS 2019 Proceedings 13, https://aisel.aisnet.org/mcis2019/13 (dostęp: 14.12.2019).

14 J.E. Kelly III, Computing, cognition and the future of knowing, IBM Research: Cognitive Computing, IBM Corporation, Retrieved February 9, New York 2016.

15 A. Jabłoński, M. Jabłoński, Modele biznesu przedsiębiorstw. Perspektywy rozwoju - ujęcie koncepcyjne, CeDeWu, Warszawa 2019, s. 174-175. 


\section{Istota kognitywnych modeli biznesu w gospodarce cyfrowej jako reprezentantów dynamicznego ujęcia}

Ponieważ Cognitive Computing stanowi niejako komputerową symulację procesów myślowych człowieka, stąd odpowiednią teorią do oceny dynamiki modeli biznesu opartych na tej koncepcji jest opisana powyżej metoda dynamiki systemowej (System Dynamics).

Najogólniej rzecz ujmując, termin ten oznacza zespół technologii, które w dużej mierze są efektem studiów nad działaniem ludzkiego mózgu. Jest to swoiste połączenie sztucznej inteligencji i przetwarzania sygnałów - dwóch elementów kluczowych dla rozwoju „świadomości maszyn”. Łączą one w sobie zestaw nowoczesnych narzędzi: samouczenie się maszyn, rozumowanie i wnioskowanie, przetwarzanie języka naturalnego, mowę, interakcje komputer - człowiek i wiele innych ${ }^{16}$. Do kluczowych trendów koncepcji algorytmów poznawczych (Cognitive Computing) zależy zaliczyć: contextual analytics, sensor generated data, cognitive visualization and influential SAAS models. Obliczenia kognitywne to wykorzystanie sztucznej inteligencji i uczenia maszynowego, aby umożliwić komputerom zrozumienie danych, wygenerowanie spostrzeżeń i wykorzystanie ich jako doświadczenia edukacyjnego w przyszłości. Za pomocą obliczeń kognitywnych łatwiej wprowadzić sztuczną inteligencję w komputerach, ponieważ zmniejsza ona nacisk na uczynienie komputerów inteligentnymi w jednym typie zadań i skalowanie zakresu zadań w wielu fazach. Wykorzystanie obliczeń kognitywnych polega na wprowadzeniu danych do inteligentnego algorytmu, który może je analizować, rozumieć korelacje i uczyć się na podstawie danych, aby automatycznie poprawić swój intelekt. Współczesne technologie są napędzane przez algorytmy, które wpisują się w założenia teorii złożoności ${ }^{17}$.

Algorytm można traktować jako skróconą nazwę socjotechnicznego asamblażu zawierającego: algorytm (w rozumieniu technicznym), model, grupę docelową, dane, aplikacje i hardware - wszystko powiązane ze środowiskiem społecznym ${ }^{18}$.

16 N. Biedrzycki, Cognitive computing, czyli jak naprawdę działa sztuczna inteligencja, https:// www.forbes.pl/opinie/cognitive-computing-jak-dziala-sztuczna-inteligencja/hfg65d6 (dostęp: 15.12.2019).

17 T.J. Sejnowski, Deep Learning, Głęboka Rewolucja. Kiedy sztuczna inteligencja spotyka się z ludzkq, Wydawnictwo Poltext, Warszawa 2019, s. 235-236.

18 J. Kreft, Władza algorytmów. U źródet potęgi Google i Facebooka, Wydawnictwo Uniwersytetu Jagiellońskiego, Kraków 2019, s. 31. 
Do realizacji założeń koncepcji algorytmów poznawczych niezbędne jest współzależne zastosowanie dużych zbiorów danych (Big Data), uczenia maszynowego (Machine Learning) oraz chmury obliczeniowej (Cloud Computing). Są to trzy główne technologie stojące za każdym poziomem przetwarzania poznawczego ${ }^{19}$. Przykładowe zastosowania tego rozwiązania wskazano w tabeli 1.

Tabela 1. Rozwiązania odpowiednie do projektowania kognitywnych modeli biznesu

\begin{tabular}{|c|l|l|}
\hline Lp. & \multicolumn{1}{|c|}{$\begin{array}{c}\text { Rodzaj } \\
\text { rozwiązania }\end{array}$} & \multicolumn{1}{c|}{ Charakterystyka } \\
\hline 1 & $\begin{array}{l}\text { Chatboty } \\
\text { (chatbots) }\end{array}$ & $\begin{array}{l}\text { Chatboty to programy, które mogą symulować ludzką rozmowę poprzez } \\
\text { rozumienie komunikacji w sensie kontekstowym. Aby to umożliwić, } \\
\text { stosuje się technikę uczenia maszynowego, zwaną przetwarzaniem } \\
\text { języka naturalnego. Przetwarzanie języka naturalnego pozwala } \\
\text { programom pobierać dane wejściowe od ludzi (głos lub tekst), } \\
\text { analizować je, a następnie udzielać logicznych odpowiedzi. Komputery } \\
\text { kognitywne pozwaląą chatbotom na komunikację z pewnym } \\
\text { poziomem inteligencji, zrozumienie potrzeb użytkownika na podstawie } \\
\text { wcześniejszej komunikacji, dawanie sugestii itp. }\end{array}$ \\
\hline 2 & $\begin{array}{l}\text { Analiza } \\
\text { sentymentów } \\
\text { (sentiment } \\
\text { analysis) }\end{array}$ & $\begin{array}{l}\text { Analiza sentymentów to nauka rozumienia emocji przekazywana } \\
\text { w komunikacji. Chociaż ludzie mogą tatwo zrozumieć ton, intencje } \\
\text { itp. w rozmowie, w przypadku maszyn jest to znacznie bardziej } \\
\text { skomplikowane. Aby umożliwić maszynom zrozumienie komunikacji } \\
\text { międzyludzkiej, należy podać dane szkoleniowe dotyczące ludzkich } \\
\text { rozmów, a następnie sprawdzić dokładność analizy. Analiza } \\
\text { sentymentów jest powszechnie stosowana do analizy komunikacji } \\
\text { w mediach spotecznościowych, takich jak tweety, komentarze, recenzje, } \\
\text { skargi itp. }\end{array}$ \\
\hline 3 & $\begin{array}{l}\text { Wykrywanie twarzy to zaawansowany poziom analizy obrazu. System } \\
\text { poznawczy wykorzystuje dane, takie jak struktura, kontury twarzy, kolor } \\
\text { oczu itp., aby odróżnić je od innych. Po wygenerowaniu obrazu twarzy } \\
\text { można go użyć do identyfikacji na podstawie obrazu lub filmu. Chociaż } \\
\text { tradycyjnie robiono to przy użyciu obrazów 2D, teraz można to również } \\
\text { zrobić przy użyciu czujników 3D, które zapewniają większą dokładność. } \\
\text { Można to wykorzystać w systemach bezpieczeństwa, takich jak kabiny, } \\
\text { a nawet telefon komórkowy. } \\
\text { detection) }\end{array}$ \\
\hline
\end{tabular}

19 What is Cognitive Computing? 5 Ways to Make Your Business More Intelligent, https://www .newgenapps.com/blog/what-is-cognitive-computing-applications-companies-artificialintelligence (dostęp: 14.12.2019). 
Tabela 1 (cd.)

\begin{tabular}{|c|l|l|}
\hline Lp. & \multicolumn{1}{|c|}{$\begin{array}{c}\text { Rodzaj } \\
\text { rozwiązania }\end{array}$} & \multicolumn{1}{c|}{ Charakterystyka } \\
\hline 4 & $\begin{array}{l}\text { Zarządzanie } \\
\text { ryzykiem (risk } \\
\text { assessment) }\end{array}$ & $\begin{array}{l}\text { Zarządzanie ryzykiem w usługach finansowych polega na analizowaniu } \\
\text { trendów rynkowych, danych historycznych itp. w celu przewidywania } \\
\text { niepewności związanej z inwestycją. Jest to jednak analiza nie tylko } \\
\text { związana z danymi, ale także z trendami, intuicją, analizą zachowań } \\
\text { itp. Jest to zatem zarówno sztuka, jak i nauka. Analiza dużych zbiorów } \\
\text { danych (tj. sama analiza wcześniejszych trendów) nie jest wystarczająca } \\
\text { do dokonania oceny ryzyka. Ze względu na intuicję i doświadczenie } \\
\text { związane z przewidywaniem przysztości rynku konieczne są inteligentne } \\
\text { algorytmy. Komputery kognitywne pomagają tączyć dane behawioralne } \\
\text { i trendy rynkowe w celu uzyskania analiz. Mogą one następnie zostać } \\
\text { zweryfikowane przez doświadczonych analityków w celu dalszej analizy } \\
\text { i prognoz. }\end{array}$ \\
\hline 5 & $\begin{array}{l}\text { Wykrywanie } \\
\text { oszustw } \\
\text { (fraud } \\
\text { Wetection) }\end{array}$ & $\begin{array}{l}\text { w finansanie oszustw to kolejne zastosowanie obliczeń kognitywnych } \\
\text { wykrywania oszustw jest identyfikacja transakcji, które nie wydają } \\
\text { się normalne (anomalii). Wymaga to również programów do analizy } \\
\text { danych z przeszłości, aby zrozumieć parametry, które należy zastosować } \\
\text { do oceny transakcji. Do wykrywania anomalii można zastosować } \\
\text { wiele technik analizy danych, takich jak regresja logistyczna, drzewo } \\
\text { decyzyjne, las losowy, klastrowanie itp. }\end{array}$ \\
\hline
\end{tabular}

Źródło: What is Cognitive Computing? 5 Ways to Make Your Business More Intelligent, https://www.newgenapps.com/blog/what-is-cognitive-computing -applications-companies-artificial-intelligence (dostęp: 14.12.2019).

Przykładami zastosowania sztucznej inteligencji, na bazie której operacjonalizowane są przedmiotowe modele biznesu w kontekście potrzeb marketingowych, są:

- technologie przetwarzania głosu (składanie zamówień przez urządzenie lub aplikację Amazon Alexa, wirtualni asystenci wspierający realizację zadań - Siri, Google Home, Cortana);

- technologie przetwarzania tekstu (wykorzystanie wirtualnego asystenta jako przewodnika po centrum handlowym - Alpine.Al);

- technologie rozpoznawania oraz przetwarzania obrazów (rozpoznanie twarzy jako sposób na realizację płatności - KFC);

- podejmowanie decyzji (indywidualne dopasowanie miejsca podróży na podstawie stylu słuchanej muzyki - Spotify, Emirates);

- autonomiczne roboty i pojazdy, bezobsługowe sklepy (Ford \& Alibaba, Amazon Go, Zaitt Brasil) ${ }^{20}$.

20 G. Mazurek, Transformacja cyfrowa. Perspektywa marketingu, Wydawnictwo Naukowe PWN, Warszawa 2019, s. 164-165. 
Tego rodzaju modele biznesu charakteryzują się naturalną dynamiką wynikającą z bezpośredniego kontaktu z obiektami zainteresowanymi projektowanymi funkcjonalnościami. Kluczowym aspektem efektywności tego typu modeli biznesu jest proces monetyzacji.

\section{Monetyzacja modeli biznesu a dynamika zmian}

Modelem monetyzacji nazywa się schemat przepływu treści, pieniędzy, interakcji i powiązań pomiędzy aktorami biorącymi udział w tym procesie ${ }^{21}$. Monetyzacja modeli biznesu opartych na algorytmach poznawczych przynależy do tej kategorii monetyzacji, która wykorzystuje duże zbiory danych. Interaktywne systemy oparte na przedmiotowych funkcjonalnościach stwarzają nowe możliwości generowania przepływów pieniężnych. Takie ujęcie procesu monetyzacji jest odmienne od innych jego form, gdyż opiera się na bezpośrednim zastosowaniu funkcjonalności technik poznawczych stanowiących wartość dla dedykowanych odbiorców. Warunkiem dostawy proponowanych funkcjonalności jest zastosowanie wielu technik analizy danych. Są to analizy nie tylko związane z danymi, ale także z trendami, intuicją, analizą zachowań itp. W sektorach, w których danych jest najwięcej, występują również największe trudności z ich wykorzystaniem i monetyzacją. Jest to kluczowy problem, gdyż głównym celem każdego modelu biznesu powinna być skuteczna monetyzacja. Monetyzacja powinna koncentrować się na wspieraniu wizji firmy poprzez implementację strategii monetyzacji, a nie tylko na samym „pakowaniu” danych do odsprzedaży. Obszarem szerokiego zastosowania kognitywnych modeli biznesu z punktu widzenia zdolności do ich monetyzacji jest marketing.

Do sposobów monetyzacji zaliczyć można rozwiązania opisane w tabeli 2.

Tabela 2. Sposoby monetyzacji

\begin{tabular}{|c|l|l|}
\hline Lp. & $\begin{array}{c}\text { Sposób } \\
\text { monetyzacji }\end{array}$ & \multicolumn{1}{c|}{ Opis } \\
\hline \multicolumn{3}{|c|}{} \\
\hline 1 & $\begin{array}{l}\text { Reklama } \\
\text { (advertising) }\end{array}$ & $\begin{array}{l}\text { Najczęstszą formą zarabiania na witrynach jest reklama. Doskonale } \\
\text { sprawdza się w witrynach medialnych, blogach oraz innych serwisach } \\
\text { informacyjnych i medialnych. Celem dostarczenia wartości jest } \\
\text { wyświetlanie reklam na tych stronach. Wymienić można kilka form } \\
\text { reklamy: reklamę kontekstową, reklamę wyświetlaną, reklamę } \\
\text { ukierunkowaną, reklamę z linkiem tekstowym. }\end{array}$ \\
\hline
\end{tabular}

21 Raport podsumowujq̨cy badanie: Wideo w sieci-Modele dystrybucji i monetyzacji plików wideo w języku polskim w sieci Internet, Krajowa Rada Radiofonii i Telewizji, 2016, s. 96, http:// www.krrit.gov.pl/Data/Files/_public/Portals/0/raporty/raport_wideo-w-sieci.pdf (dostęp: 14.12.2019). 
Tabela 2 (cd.)

\begin{tabular}{|c|c|c|}
\hline Lp. & $\begin{array}{c}\text { Sposób } \\
\text { monetyzacji }\end{array}$ & Opis \\
\hline 2 & $\begin{array}{l}\text { Sponsoring } \\
\text { (sponsorship) }\end{array}$ & $\begin{array}{l}\text { Inny charakter niż reklama ma sponsoring. Sponsorzy są często } \\
\text { wprowadzani do witryn internetowych lub do mediów. Ich } \\
\text { operacjonalizacja może opierać się na takich rozwiązaniach jak } \\
\text { transmisja na żywo informacji lub wirusowa kampania marketingowa. }\end{array}$ \\
\hline 3 & $\begin{array}{l}\text { Płatne treści } \\
\text { i reklamy (paid } \\
\text { content and } \\
\text { advertorials) }\end{array}$ & $\begin{array}{l}\text { Często w czasopismach i gazetach można zobaczyć sekcje reklamowe, } \\
\text { które - na pierwszy rzut oka - wydają się redakcją publikacji. W tych } \\
\text { płatnych obszarach treści udostępniana jest użyteczna lub cenna } \\
\text { wiedza, która jednocześnie prowadzi użytkownika w kierunku } \\
\text { marketingu. Witryny medialne mogą oferować sekcje reklamowe } \\
\text { na swoich stronach, umożliwiając marketerom publikowanie treści. }\end{array}$ \\
\hline 4 & $\begin{array}{l}\text { Dystrybucja } \\
\text { treści } \\
\text { (syndication } \\
\text { of content) }\end{array}$ & $\begin{array}{l}\text { Zmiana przeznaczenia treści z innych kanałów lub wyświetlanie } \\
\text { treści na innych stronach internetowych może przynieść resztkowe } \\
\text { przychody z mikropłatności lub stałej ceny. Wyświetlanie treści z innych } \\
\text { źródeł może spowodować, że zostanie zapewniony transfer płatności } \\
\text { pomiędzy dostawcami treści. }\end{array}$ \\
\hline 5 & $\begin{array}{l}\text { Przynależność } \\
\text { (affiliations) }\end{array}$ & $\begin{array}{l}\text { W przypadku wielu stron internetowych podawanie zalecanych linków } \\
\text { do partnerów może stanowić stały strumień linków i przychodów } \\
\text { z prowizji. Przykładem tego jest program rekomendacji książek } \\
\text { spółki Amazon. Ważne, aby strona była w pełni przejrzysta, jeśli } \\
\text { chodzi o związek linków i rekomendacji. Firmy, które agregują treści } \\
\text { i dystrybuują je do innych firm, mogą otrzymywać mikropłatności } \\
\text { za takie działania, na przykład Firefox Mozilli generuje regularne kwoty } \\
\text { mikropłatności od użytkowników, którzy używają paska wyszukiwania } \\
\text { w prawym górnym rogu przeglądarki. }\end{array}$ \\
\hline 6 & $\begin{array}{l}\text { Dotacja/ } \\
\text { donacja/ } \\
\text { darowizna } \\
\text { (donations) }\end{array}$ & $\begin{array}{l}\text { Umieszczanie propozycji donacji odbywa się najczęściej pod } \\
\text { segmentem Marketing, ponieważ te same rodzaje działań są wymagane } \\
\text { do uzyskania darowizn od grup lub osób. Ta powszechna metoda } \\
\text { wymaga przekazania pieniędzy na rzecz danego przedsięwzięcia } \\
\text { - często społecznego. }\end{array}$ \\
\hline 7 & $\begin{array}{l}\text { Konwersja } \\
\text { (conversion) }\end{array}$ & $\begin{array}{l}\text { Nie wszystkie strony internetowe generują bezpośrednie przychody, } \\
\text { chociaż marketerzy mogą przybliżać potencjalnych klientów do punktu } \\
\text { sprzedaży. W niektórych firmach, które dostarczają wykwalifikowanych } \\
\text { potencjalnych klientów, zarabia się dla tych potencjalnych klientów. } \\
\text { Strony internetowe mogą generować zainteresowanie z działań } \\
\text { marketingowych, działań kwalifikacyjnych, które ostatecznie prowadzą } \\
\text { do sprzedaży. }\end{array}$ \\
\hline \multicolumn{3}{|r|}{ Monetyzacja poprzez źródła finansowania } \\
\hline 8 & $\begin{array}{l}\text { Nabycie } \\
\text { (acquisition) }\end{array}$ & $\begin{array}{l}\text { Najczęściej omawianym procesem transakcyjnym w dzisiejszych } \\
\text { uwarunkowaniach start-upów jest możliwość zakupu ich przez dużą } \\
\text { jednostkę internetową. }\end{array}$ \\
\hline 9 & $\begin{array}{l}\text { Oferta } \\
\text { publiczna } \\
\text { (initial public } \\
\text { offerings) }\end{array}$ & $\begin{array}{l}\text { Początkowa oferta publiczna to sposób, w jaki firma sprzedaje własność } \\
\text { spółki publicznie, a nabywcy stają się udziałowcami, by ostatecznie } \\
\text { wartość udziatów (i firmy) wzrosta. Ta forma monetyzacji znacznie się } \\
\text { zmniejszyła w } 2007 \text { r. i obecnie jest bardzo rzadka. }\end{array}$ \\
\hline
\end{tabular}




\begin{tabular}{|c|l|l|}
\hline Lp. & \multicolumn{1}{|c|}{$\begin{array}{c}\text { Sposób } \\
\text { monetyzacji }\end{array}$} & \multicolumn{1}{c|}{ Opis } \\
\hline 10 & $\begin{array}{l}\text { Inwestycje } \\
\text { i partnerstwo } \\
\text { (investment } \\
\text { and } \\
\text { partnership) }\end{array}$ & $\begin{array}{l}\text { Wiele start-upów jest finansowanych przez firmy typu venture capital } \\
\text { lub dużych partnerów. Działanie to często nie jest uznawane za metodę } \\
\text { monetyzacji, ale tak naprawdę utrzymuje tych, którzy prowadzą } \\
\text { witrynę, mając możliwości rozwoju. }\end{array}$ \\
\hline \multicolumn{3}{|c|}{ Monetyzacja poprzez usługi } \\
\hline 11 & $\begin{array}{l}\text { Handel } \\
\text { elektroniczny } \\
\text { (e-commerce) }\end{array}$ & $\begin{array}{l}\text { Sprzedaż towarów on-line i przekazywanie im rekomendacji zapewnia } \\
\text { sprzedającemu możliwość czerpania zysków ze sprzedaży własnych } \\
\text { towarów, a także hurtownikom lub pośrednikom. }\end{array}$ \\
\hline 12 & $\begin{array}{l}\text { Premium, } \\
\text { członkostwa } \\
\text { i licencje } \\
\text { (premium, } \\
\text { memberships, } \\
\text { and licensing) }\end{array}$ & $\begin{array}{l}\text { Wspólne dla stron internetowych oferujących bezpłatną usługę pełne } \\
\text { członkostwo lub ekskluzywne członkostwo zapewniają użytkownikom } \\
\text { dodatkowe korzyści. Kilka przykładów obejmuje ustugi pocztowe } \\
\text { oferujące dodatkową przestrzeń dyskową, flickr oferujący większą } \\
\text { pojemność przesyłania zdjęć lub dostęp do innych stron internetowych. } \\
\text { Może to również obejmować opcje licencjonowania oprogramowania. }\end{array}$ \\
\hline 13 & $\begin{array}{l}\text { Dobra } \\
\text { wirtualne } \\
\text { (virtual goods) }\end{array}$ & $\begin{array}{l}\text { Ta forma monetyzacji stale rośnie w sieciach spotecznościowych } \\
\text { i wirtualnych witrynach. Obiekty (rzeczywiste i wirtualne) generują } \\
\text { wartość pieniężną. }\end{array}$ \\
\hline Monetyzacja z tytułu korzyści z posiadania aplikacji i dostępu do dużych zbiorów danych \\
\hline 14 & $\begin{array}{l}\text { Sprzedaż } \\
\text { danych (selling } \\
\text { data) }\end{array}$ & $\begin{array}{l}\text { Wiele witryn gromadzi informacje, które można odsprzedawać } \\
\text { stronom trzecim. Danymi mogą być: ruch internetowy, wyszukiwane } \\
\text { hasła, informacje rejestracyjne, informacje e-mail. Podczas } \\
\text { gromadzenia informacji należy być otwartym i przejrzystym dla swoich } \\
\text { użytkowników. }\end{array}$ \\
\hline 15 & $\begin{array}{l}\text { Dodatkowe } \\
\text { możliwości } \\
\text { (secondary } \\
\text { opportunities) }\end{array}$ & $\begin{array}{l}\text { Możliwości rozszerzenia marki na inne media mogą generować } \\
\text { przychody. W szczególności dotyczy to nowych ofert pracy, możliwości } \\
\text { mówienia, pisania oraz syndykacji treści. }\end{array}$ \\
\hline
\end{tabular}

Źródło: opracowanie własne na podstawie J. Owyang, Explaining what the social graph is to your executive (Web strategy), 2007, http://www.web-strategist.com./blog/2007/11/10/ (dostęp: 14.12.2019).

Pojęcie monetyzacji można wyjaśnić szerzej na przykładzie procesu spieniężania treści wideo w internecie. Opiera się ona na udziale czterech aktorów: widza, platformy, reklamodawcy i twórcy. W zależności od relacji pomiędzy poszczególnymi aktorami można wyróżnić odmienne typy modeli spieniężania treści. Monetyzacja materiałów wideo może mieć charakter pośredni lub bezpośredni. Monetyzacja pośrednia opiera się na sprzedaży generowanego ruchu, natomiast bezpośrednia polega na sprzedawaniu towaru i usług. Do schematów monetyzacji pośredniej zalicza się:

- opłatę za kliknięcie (pay per click - PPC);

- opłatę za wyświetlenia (cost per mille - CPM, z łac. mille - 'tysiąc');

- opłatę za działania (cost per action - CPA), w ramach której wyróżnia się:

- opłatę za sprzedaż (cost per sale - CPS);

- opłatę za leady (cost per lead - CPL). 
Sposoby monetyzacji wideo w sieci, czyli reklama, crowdfunding, sponsoring, subskrypcja, product placement oraz e-commerce stanowią inną kategorię monetyzacji niż typy monetyzacji (bezpośredniej i pośredniej). Nie należy ich więc ze sobą utożsamiać, ponieważ nie ma przeszkód, aby jakiś sposób spieniężania łączył typy monetyzacji pośredniej i bezpośredniej ${ }^{22}$.

Do rodzajów monetyzacji w zakresie spieniężania treści wideo $\mathrm{w}$ internecie można między innymi zaliczyć formuły opisane w tabeli 3.

Tabela 3. Sposoby monetyzacji

\begin{tabular}{|c|l|l|}
\hline Lp. & $\begin{array}{c}\text { Formuta } \\
\text { monetyzacji }\end{array}$ & \multicolumn{1}{c|}{ Opis } \\
\hline 1 & $\begin{array}{l}\text { Model } \\
\text { rynkowy }\end{array}$ & $\begin{array}{l}\text { Twórca wytwarza materiat wideo, który publikuje na platformie self- } \\
\text { publishingowej. Następnie treść wideo jest udostępniana przez platformę, } \\
\text { czego efektem jest dostarczenie jej do widzów, którzy mają możliwość } \\
\text { bezpośredniego oglądania treści w serwisie i rozpowszechnienia ich } \\
\text { wśród znajomych oraz na inne platformy czy sieci spotecznościowe. } \\
\text { Widz staje się konsumentem, potencjalnym klientem - przenosi się } \\
\text { z serwisu wideo na zewnętrzną stronę internetową, gdzie może dokonać } \\
\text { zakupu (e-commerce) produktu fizycznego lub cyfrowego, którego } \\
\text { autorem i sprzedawcą byt twórca wideo. Pieniądze z dokonanego zakupu } \\
\text { trafiają do twórcy (typ monetyzacji bezpośredniej). W tym konkretnym } \\
\text { modelu platforma nie generuje przychodu, ponieważ twórca za darmo } \\
\text { opublikowat i udostępnit materiat. }\end{array}$ \\
\hline 2 & $\begin{array}{l}\text { W modelu zwrotnym za doptyw pieniędzy odpowiedzialny jest reklamo- } \\
\text { dawca, natomiast twórca dostarcza do serwisu materiat wideo. Co ważne, } \\
\text { działania reklamodawców i twórców są od siebie niezależne. Następnie } \\
\text { treść jest udostępniana przez platformę, czego efektem jest dostarczenie } \\
\text { jej do widzów, którzy mają możliwość bezpośredniego oglądania treści } \\
\text { w serwisie i rozpowszechnienia ich wśród znajomych oraz na inne platfor- } \\
\text { my czy sieci spotecznościowe. Widzom, oprócz docelowych treści wideo, } \\
\text { wyświetlane są materiaty promocyjne reklamodawców. Dobór reklam } \\
\text { do treści wideo nie jest jednak przypadkowy. }\end{array}$ \\
\hline
\end{tabular}

22 Raport podsumowujqcy badanie: Wideo w sieci .... 


\begin{tabular}{|c|c|c|}
\hline Lp. & $\begin{array}{c}\text { Formuła } \\
\text { monetyzacji }\end{array}$ & Opis \\
\hline 3 & $\begin{array}{l}\text { Model popu- } \\
\text { laryzacyjny }\end{array}$ & $\begin{array}{l}\text { Model popularyzacyjny to model, w którym efektem monetyzacji } \\
\text { są środki niemożliwe do wykorzystania (zrealizowania podczas transakcji) } \\
\text { na innych rynkach. Model ten jest w zasadzie podobny do modelu } \\
\text { rynkowego, choć wyraźnie rozróżnia je końcowe dobro. Stworzony } \\
\text { materiat wideo jest udostępniany przez platformę, czego efektem jest } \\
\text { dostarczenie go do widzów, którzy mają możliwość bezpośredniego } \\
\text { oglądania treści w serwisie i rozpowszechnienia ich wśród znajomych } \\
\text { oraz na inne platformy czy sieci społecznościowe. Następnie widz staje } \\
\text { się konsumentem - przegląda wcześniejsze dzieła autora, wchodzi } \\
\text { na jego stronę internetową, komentuje materiat i udostępnia go swoim } \\
\text { znajomym. Wszystkie interakcje wykonywane przez konsumenta wracają } \\
\text { do twórcy w postaci szerszego grona odbiorców. To z kolei przekłada } \\
\text { się na potencjat reklamowy twórcy (typ monetyzacji pośredniej), czyli } \\
\text { determinuje jego przyszłe przychody. }\end{array}$ \\
\hline 4 & $\begin{array}{l}\text { Model popu- } \\
\text { laryzacyjno- } \\
\text {-rynkowy }\end{array}$ & $\begin{array}{l}\text { Model, który poniekąd tączy ze sobą dwa wcześniej omówione schematy, } \\
\text { to model popularyzacyjno-rynkowy. Popularny twórca jest opłacany przez } \\
\text { reklamodawcę (poprzez sponsoring czy product placement), co stanowi } \\
\text { przykład monetyzacji bezpośredniej. Firma inwestuje wymierne środki, } \\
\text { aby stać się bardziej rozpoznawalną w konkretnej grupie wiekowej, rozpo- } \\
\text { wszechnić albo sprzedać swój produkt. Twórca sporządza materiał wideo, } \\
\text { który publikuje na platformie self-publishingowej. Następnie treść wideo } \\
\text { jest udostępniana przez platformę, czego efektem jest dostarczenie jej } \\
\text { do widzów, którzy mają możliwość bezpośredniego oglądania treści w ser- } \\
\text { wisie i rozpowszechnienia ich wśród znajomych oraz na inne platformy } \\
\text { czy sieci spotecznościowe. }\end{array}$ \\
\hline 5 & $\begin{array}{l}\text { Model } \\
\text { pośrednio } \\
\text { rynkowy }\end{array}$ & $\begin{array}{l}\text { Model nawiązuje do symbiotycznej relacji pomiędzy twórcami. Zarówno } \\
\text { twórca nr } 1 \text {, jak i twórca nr } 2 \text { otrzymują wymierną, materialną korzyść. Tak } \\
\text { jak w poprzednim modelu, to twórca nr } 2 \text { jest inwestorem dostarczającym } \\
\text { środki popularniejszemu twórcy nr } 1 \text {. Twórca nr } 1 \text { wytwarza materiat } \\
\text { wideo, który publikuje na platformie self-publishingowej. Następnie treść } \\
\text { wideo jest udostępniana przez platformę, czego efektem jest dostarczenie } \\
\text { jej do widzów, którzy mają możliwość bezpośredniego oglądania treści } \\
\text { w serwisie i rozpowszechnienia ich wśród znajomych oraz na inne platfor- } \\
\text { my czy sieci społecznościowe. Treść wideo lub jej opis zawiera odnośnik } \\
\text { do zewnętrznej strony, na której widz staje przed możliwością zakupu } \\
\text { produktów twórcy nr } 2 \text { (e-commerce). Finalnie widzowie generują zysk dla } \\
\text { twórcy nr } 2 \text {, co jest przykładem monetyzacji bezpośredniej. }\end{array}$ \\
\hline
\end{tabular}


Tabela 3 (cd.)

\begin{tabular}{|c|l|l|l|}
\hline Lp. & $\begin{array}{c}\text { Formuta } \\
\text { monetyzacji }\end{array}$ & \multicolumn{1}{c|}{ Opis } \\
\hline 6 & $\begin{array}{l}\text { Model } \\
\text { pośrednio } \\
\text { popularyza- } \\
\text { cyjny }\end{array}$ & $\begin{array}{l}\text { W modelu pośrednio popularyzacyjnym występuje dwóch twórców. } \\
\text { Twórca nr 1 otrzymuje wymierną korzyść finansową za działania } \\
\text { promocyjne na rzecz twórcy nr 2. Realizacja tego modelu przebiega } \\
\text { według następującego schematu: twórca nr 2 inwestuje w reklamę } \\
\text { swojego dzieła lub serii wideo - pieniądze przekazuje jednak bardziej } \\
\text { znanemu twórcy nr 1, dysponującemu odpowiednim potencjatem } \\
\text { reklamowym. Twórca nr 1 produkuje promujące twórcę nr 2 wideo, } \\
\text { które publikuje na platformie self-publishingowej. Następnie treść wideo } \\
\text { jest udostępniana przez platformę, czego efektem jest dostarczenie jej } \\
\text { do widzów, którzy mają możliwość bezpośredniego oglądania treści } \\
\text { w serwisie i rozpowszechnienia ich wśród znajomych oraz na inne } \\
\text { platformy czy sieci spotecznościowe. Widzowie wchodzą w interakcję } \\
\text { z zareklamowanym twórcą nr 2, przez co wzrasta jego popularność } \\
\text { i potencjat reklamowy (typ monetyzacji pośredniej). Pomiędzy twórcami } \\
\text { zachodzi protokooperacja - wspótpracują ze sobą i odnoszą z tego } \\
\text { wzajemne korzyści. }\end{array}$ \\
\hline 7 & $\begin{array}{l}\text { Widzowie przekazują twórcy środki pieniężne, które finansują proces } \\
\text { produkcyjny treści wideo (typ monetyzacji bezpośredniej). Twórca } \\
\text { wytwarza materiat wideo, a następnie publikuje go na platformie self- } \\
\text { publishingowej. Platforma daje moźliwość odtwarzania i udostępniania } \\
\text { wideo, czego efektem jest dotarcie do widzów (dystrybucja). Widzowie, } \\
\text { którzy byli fundatorami projektu, otrzymują świadczenie zwrotne } \\
\text { - konkretną wartość, czyli np. oczekiwany (zamawiany) film. }\end{array}$ \\
\hline
\end{tabular}

Źródło: opracowanie własne na podstawie Raport podsumowujqcy badanie: Wideo w sieci..., s. 97-104, http://www.krrit.gov.pl/Data/Files/_public/Por tals/0/raporty/raport_wideo-w-sieci.pdf (dostęp: 14.12.2019).

\section{Monetyzacja jako czynnik dynamizujący modele biznesu - próba konceptualizacji}

Jak już wcześniej zaznaczono, monetyzacja to schemat przepływu treści, pienię$\mathrm{dzy}$, interakcji i powiązań pomiędzy aktorami biorącymi udział w tym procesie. Monetyzacja stymuluje zatem relacje zachodzące pomiędzy aktorami biorącymi udział w sieci powiązań determinowanych logiką przyjętego modelu biznesu. Jest więc kluczowym elementem przyjętego rozwiązania biznesowego, silnie powiązanym z propozycją oferowanej wartości. Monetyzacja dynamizuje model biznesu $\mathrm{w}$ tym sensie, że jest jego istotą. Z ekonomicznego punktu widzenia warunkiem przetrwania danego modelu biznesu jest potrzeba spełnienia trzech warunków:

- aktorzy skupieni wokół modelu biznesu muszą dostrzegać korzyści z tytułu dostarczanej w ramach modelu biznesu propozycji wartości;

- aktorzy muszą akceptować proponowany sposób monetyzacji; 
- przepływ pieniężny nie musi być adekwatny w swojej wielkości do schematu dostawy wartości.

Na rysunku 1 przedstawiono autorski sposób prezentacji działania monetyzacji w kontekście cyfrowych modeli biznesu. Najczęściej klient/użytkownik dokonuje transferu środków finansowych na platformę cyfrową, która za pośrednictwem wspierających ją operatorów dostarcza oczekiwaną wartość. Przepływ proponowanej wartości może być symetryczny lub niesymetryczny, co wynika z rodzaju monetyzacji - bezpośredniej lub pośredniej. W przypadku monetyzacji bezpośredniej za dostarczaną wartości dokonywany jest przepływ pieniędzy, wtedy też zachowana jest symetria między obiema zmiennymi.

W sytuacji gdy przychód z tytułu dostawy wartości za pośrednictwem modelu biznesu nie jest powiązany z ową dostawą wartości, występuje zjawisko monetyzacji pośredniej. W przypadku monetyzacji pośredniej nie ma symetrii między wartością dostarczaną poprzez model biznesu a przepływem pieniędzy. Oba te rozwiązania stanowią podstawę do funkcjonowania cyfrowych modeli biznesu.

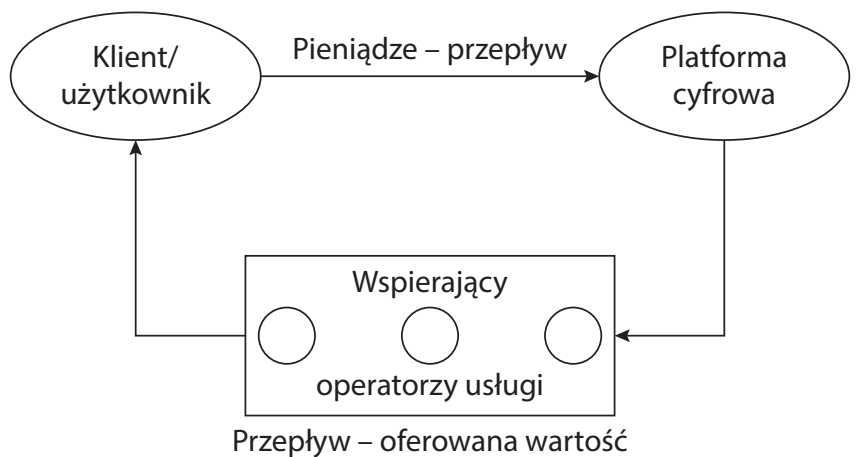

Rysunek 1. Ogólny schemat monetyzacji cyfrowego modelu biznesu Źródto: opracowanie własne.

Zaprezentowany ogólny schemat monetyzacji cyfrowego modelu biznesu obrazuje relacyjny charakter funkcjonowania współczesnej gospodarki światowej. $\mathrm{Z}$ modelu transakcyjnego następuje przejście do modelu relacyjnego ${ }^{23}$, co stwarza możliwości rozwoju schematów monetyzacji pośredniej. Będzie miało to znaczenie w przypadku monetyzacji modeli biznesu działających w ramach koncepcji ekonomii współdzielenia (Sharing Economy). W skład modelu biznesu gospodarki współdzielenia wchodzą: firma lub aktywator usług, który działa jako pośrednik między dostawcami towarów lub usług (usługodawca) oraz klienci, którzy wymagają

23 Szeroko na ten temat: J. Hausner, Społeczna czasoprzestrzeń gospodarowania, w kierunku ekonomii wartości, Wydawnictwo Nieoczywiste, Warszawa 2019, s. 205-208. 
wsparcia opartego na przedmiotowym pośrednictwie wymiany niewykorzystanych towarów i usług. Wzajemnie systemowe powiązania między aktorami budują schemat monetyzacji tak określonych modeli biznesu ${ }^{24}$. Monetyzacja będzie zatem zależeć także od przyjętej koncepcji nowej gospodarki, na przykład koncepcji ekonomii współdzielenia, gospodarki okrężnej lub systemów dużych zbiorów danych. W każdym odmiennym podejściu do kreowania wartości monetyzacja będzie opierać się na innych założeniach, co będzie miało odniesienie do koncepcji dynamiki modeli biznesu.

\section{Uwagi końcowe}

Dynamika modeli biznesu objawia się ich zdolnością do zmian, a także wielowariantowym sposobem monetyzacji. Im szybsza zdolność modelu do zmian, tym większa zdolność do stałego kreowania wartości. Im więcej scenariuszy monetyzacji zabudowanych w logice modelu biznesu, tym większe szanse na uzyskanie oczekiwanego ekonomicznego wyniku. Dynamiczność oceniana w toku analizy współczesnych modeli biznesu stanowi kluczowy atrybut odpowiedzialny za zapewnienie zdolności przedsiębiorstwa do przetrwania w kontekście zastosowania konkretnego modelu biznesu oraz sposobu jego monetyzacji.

Na podstawie przeprowadzonych badań literaturowych oraz konceptualizacji zagadnienia dynamiki modeli biznesu przedsiębiorstw w gospodarce cyfrowej z punktu widzenia perspektywy monetyzacji można sformułować kilka kluczowych wniosków końcowych:

- Metoda dynamiki systemowej (System Dynamics) umożliwia budowę modeli symulacji ciągłej, które wpisują się w schemat funkcjonowania modeli biznesu wchodzących w interakcję z użytkownikami, doskonaląc procesy relacyjne służące monetyzacji.

- Dobrym przykładem zastosowania dynamiki w modelach biznesu są doświadczenia z projektowania kognitywnych modeli biznesu, których założeniem jest zastosowanie zespołu technologii, w dużej mierze będących efektem studiów nad działaniem ludzkiego mózgu. Stanowią swoiste połączenie sztucznej inteligencji i przetwarzania sygnałów - dwóch elementów kluczowych dla rozwoju „świadomości maszyn”.

- Monetyzacja, rozumiana jako schemat przepływu treści, pieniędzy, interakcji i powiązań pomiędzy aktorami biorącymi udział w relacji biznesowej realizowanej w ramach określonej platformy technologicznej, stymuluje relacje

24 V. Kumar, A. Lahiri, O. Bahadir Dogan, A strategic framework for a profitable business model in the sharing Economy, „Industrial Marketing Management” 2018, no. 69, s. 148. 
zachodzące pomiędzy aktorami biorącymi udział w sieci powiązań determinowanych logiką przyjętego modelu biznesu.

- Nowoczesne schematy monetyzacji cyfrowych modeli biznesu wpisują się w relacyjny charakter funkcjonowania współczesnej gospodarki światowej, odchodząc od modelu transakcyjnego.

- Monetyzacja, jako schemat generowania wyników ekonomicznych, jest odmienna od standardowego modelu generowania przychodów z działalności operacyjnej, gdyż jej założenia opierają się na systemowym podejściu polegającym na wpisaniu się owego schematu generowania przepływów pieniężnych w logikę cyfrowego modelu biznesu. Przepływy pieniężne nie muszą być powiązane z łańcuchem wartości.

- W przypadku monetyzacji pośredniej występuje zjawisko braku symetrii między wartością dostarczaną poprzez model biznesu a przepływem pieniędzy. Nie wpływa to przy tym na efektywność przyjętego rozwiązania.

- Z punktu widzenia doskonalenia efektywności funkcjonowania cyfrowych modeli biznesu warunkiem ich przetrwania jest potrzeba spełnienia trzech fundamentalnych warunków:

- aktorzy skupieni wokół modelu biznesu muszą dostrzegać korzyści z tytułu dostarczanej w ramach modelu biznesu propozycji wartości;

- aktorzy muszą akceptować proponowany sposób monetyzacji;

- przepływ pieniężny nie musi być adekwatny w swojej wielkości do schematu dostawy wartości.

- W toku studiów na temat sposobu monetyzacji można wyróżnić kilka ich rodzajów:

- monetyzacja oparta na wykorzystaniu atrybutów logiki modelu biznesu;

- monetyzacja poprzez źródła finansowania;

- monetyzacja poprzez usługi;

- monetyzacja z tytułu korzyści z posiadania aplikacji i dostępu do dużych zbiorów danych.

- Innym podziałem schematów monetyzacji jest podział opierający się na strukturze relacji pomiędzy aktorami biorącymi udział w systemie dynamicznej wymiany wartości w sieci powiązań. Tutaj monetyzacja jest wynikiem współpracy podmiotów stanowiących konfigurację relacji owych podmiotów w ramach modelu biznesu.

Powyższe konkluzje nie wyczerpują zaprezentowanego problemu naukowego, ale w pewnym stopniu wskazują kluczowe kierunki rozważań, które autorzy pragną rozwijać w dalszych pracach naukowych poświęconych zagadnieniu dynamiki modeli biznesu w powiązaniu z koncepcją monetyzacji. 
Bibliografia

Baden-Fuller C., Mangematin V., Business Models: A challenging agenda, „Strategic Organization” 2013, vol. 11, no. 4, s. 418-427.

Bataineh A.S., Mizouni R., Barachi M.E., Bentahar J., Monetizing Personal Data: A Two-Sided Market Approach, „Procedia Computer Science” 2016, no. 83, s. 472-479.

Biedrzycki N., Cognitive computing, czylijak naprawdę działa sztuczna inteligencja, https://www .forbes.pl/opinie/cognitive-computing-jak-dziala-sztuczna-inteligencja/hfg65d6 (dostęp: 15.12.2019).

Blaschke M., Cigaina M., Riss U.V., Shoshan I., Designing Business Models for the Digital Economy, [w:] G. Oswald, M. Kleinemeier (red.), Shaping the Digital Enterprise, Springer International Publishing, Switzerland 2017, s. 121-136.

Clemons E.K., The complex problem of monetizing virtual electronic social networks, „Decision Support Systems" 2009, vol. 48, no. 1, s. 46-56.

Forrester J.W., Some Basic Concepts in System Dynamics, Sloan School of Management Massachusetts Institute of Technology, Cambridge 2009.

Hausner J., Społeczna czasoprzestrzeń gospodarowania, w kierunku ekonomii wartości, Wydawnictwo Nieoczywiste, Warszawa 2019.

Hoffmann R., Protasowicki T., Metoda dynamiki systemowej w modelowaniu złożonych systemów i procesów, „Biuletyn Instytutu Systemów Informatycznych” 2013, t. 12, s. 19-28.

Jabłoński A., Jabłoński M., Modele biznesu przedsiębiorstw. Perspektywy rozwoju - ujęcie koncepcyjne, CeDeWu, Warszawa 2019.

Jabłoński A., Jabłoński M., Social Business Models in the Digital Economy, New Concepts and Contemporary Challenges, Palgrave Macmillan, Springer Nature, Switzerland 2020.

Jabłoński M., Labilność modeli biznesu a zarzq̨dzanie interfejsami w koncepcji ekonomii wspótdzielenia, „Przegląd Organizacji” 2017, nr 9, s. 13-21.

Kelly III J.E., Computing, cognition and the future of knowing, IBM Research: Cognitive Computing, IBM Corporation, Retrieved February 9, New York 2016.

Kreft J., Władza algorytmów. U źródet potęgi Google i Facebooka, Wydawnictwo Uniwersytetu Jagiellońskiego, Kraków 2019.

Kumar V., Lahiri A., Bahadir Dogan O., A strategic framework for a profitable business model in the sharing economy, „Industrial Marketing Management” 2018, no. 69, s. 147-160.

Mazurek G., Transformacja cyfrowa. Perspektywa marketingu, Wydawnictwo Naukowe PWN, Warszawa 2019.

Owyang J., Explaining what the social graph is to your executive (Web strategy), 2007, http://www .web-strategist.com./blog/2007/11/10/ (dostęp: 14.12.2019).

Raport podsumowujący badanie: Wideo w sieci - Modele dystrybucji i monetyzacji plików wideo w języku polskim w sieci Internet, Krajowa Rada Radiofonii i Telewizji, 2016, http://www.krrit.gov.pl/Data/Fi les/_public/Portals/0/raporty/raport_wideo-w-sieci.pdf (dostęp: 14.12.2019).

Schaffer N., Pfaff M., Krcmar H., Dynamic business models: a comprehensive classification of literature, MCIS 2019 Proceedings 13, https://aisel.aisnet.org/mcis2019/13 (dostęp: 14.12.2019).

Sejnowski T.J., Deep Learning, Głęboka Rewolucja. Kiedy sztuczna inteligencja spotyka się z ludzkq, Wydawnictwo Poltext, Warszawa 2019.

Teece D.J., Business models and dynamic capabilities, „Long Range Planning” 2018, vol. 51, no. 1, S. 40-49.

Timmers P., Business Models for Electronic Markets, „Electronic Markets” 1998, vol. 8, no. 2, s. 3-8.

What is Cognitive Computing? 5 Ways to Make Your Business More Intelligent, https://www.new genapps.com/blog/what-is-cognitive-computing-applications-companies-artificial-intel ligence (dostęp: 14.12.2019). 
Żukowski P., Podstawy budowy modelu dynamiki systemu zarzq̨dzania oraz jego symulacja w organizacji gospodarczej (na podstawie metodologii dynamiki systemów J.W. Forrestera), „Przedsiębiorczość - Edukacja, Rola Przedsiębiorczości w Edukacji” 2012, t. 8, s. 331-347.

\section{Streszczenie}

Transformacja cyfrowa tworzy nowe perspektywy rozwoju modeli biznesu. Wynikiem tego procesu jest pojawianie się nowych sposobów ich monetyzacji. Kreuje to nowy wymiar osiągania wysokiej efektywności przedsiębiorstw funkcjonujących w ekosystemie cyfrowym. Zmieniająca się logika prowadzenia biznesu otwiera drogę do tworzenia nowych modeli biznesu i ich dalszej ewolucji. W tym kontekście cyfrowe modele biznesu przechodzą do wyższej fazy rozwoju, stając się kognitywnymi modelami biznesu. Kognitywne modele biznesu bazują na nowych algorytmach uczenia się, wspieranych wielowymiarową analityką biznesową, oraz na dynamicznym wnioskowaniu z silnym zaangażowaniem klientów. Może to być osiągnięte poprzez wprowadzenie do cyfrowych modeli biznesu dynamiki przyspieszającej ich dalszą eksplorację i eksploatację, z uwzględnieniem elastycznych, inteligentnych rozwiązań odpowiedzialnych za dostawę wartości zabudowanych w usługach. Wtedy pojawiają się nowe i inteligentne sposoby dostawy wartości. Czynnikiem stymulującym dynamikę modeli biznesu jest monetyzacja. Schematy monetyzacji silnie oddziałują na atrakcyjność cyfrowych modeli biznesu. Celem opracowania jest przedstawienie wyników badań bibliograficznych służących identyfikacji i charakterystyce kluczowych determinant odpowiedzialnych za dynamikę modeli biznesu funkcjonujących w środowisku cyfrowym. Zakres rozdziału obejmuje zasady projektowania i implementacji modeli biznesu osadzonych w ekosystemie cyfrowym w kontekście różnych schematów monetyzacji.

Słowa kluczowe: transformacja cyfrowa, modele biznesu, gospodarka cyfrowa, dynamika

\section{Dynamics of cognitive business models of enterprises in the digital economy}

\section{Abstract}

Digital transformation creates new perspectives for the development of business models. The result of this process is the emergence of new ways of monetizing them. This creates a new dimension in achieving high efficiency for enterprises operating in the digital ecosystem. The changing business logic opens the way to creating new business models and their further evolution. In this context, digital business models are transforming into their higher stage of development becoming cognitive business models. Cognitive business models are based on new learning algorithms supported by multidimensional business analytics and dynamic inference with strong customer involvement. This can be achieved by introducing dynamics to digital business models, accelerating their further exploration and exploitation, including flexible intelligent solutions embedded in services. Then new and intelligent ways of delivering value appear. Monetization is a factor that stimulates the dynamics of business models. Monetization schemes strongly influence the attractiveness of digital business models. The aim of the article is to present the results of bibliographic research used to identify and characterize 
key determinants responsible for the dynamics of business models functioning in the digital environment. The scope of the article includes the principles of design and implementation of business models embedded in the digital ecosystem in the context of various monetization schemes.

Keywords: digital transformation, business models, digital economy, dynamics

JEL Classification System: M13 